Vol. 5, No. 1, 2019

УДК: 323:351

https://doi.org/10.23939/shv2019.01.013

\title{
INTERNATIONAL BROADCASTING AS A FORM OF FOREIGN-POLICY MEDIA COMMUNICATIONS OF MODERN STATES: EXPERIENCE FOR UKRAINE
}

\author{
Uliana llnytska \\ Lviv Polytechnic National University \\ uv11@i.ua \\ ORCID: 0000-0002-9103-3144
}

(стаття надійшла до редколегії-1.03.2019 р., стаття прийнята до друку - 20.04.2019 р.)

\section{() Ільницькка У., 2019}

The article provides a thorough investigation of the problem of the effectiveness of international broadcasting in the system of foreign-policy media communications of modern states with the aim of introducing and using positive foreign experience for Ukraine. The paper analyzes the importance of international broadcasting in the implementation of foreignpolicy strategies of modern states and its determining role in positioning and popularization of those states in the international arena or creating a positive public perception of a certain country. The authors prove that the efficiently organized international broadcasting system implies an effective form of communication between a definite country and the world community, an important direction of thelits foreign policy, an effective tool in promoting the national interests, state information sovereignty preservation, and also a powerful mechanism for preventing and counteracting disinformation, propaganda, and other negative info-psychological impacts.

The article describes the main formative stage of international broadcasting as a constituent of media communications of the modern states; the authors analyze the organizational and politico-legal foundations and principles of functioning of the international broadcasting system of the lead foreign countries in the global information space.

As a result of a comprehensive study of the formation and transformation of Ukraine's international broadcasting system and the analysis of the legal framework and functioning principles we should acknowledge inefficiency and low effectiveness of Ukraine's international broadcasting. Based on the analysis of foreign experience of the functioning of the international broadcasting institutes we provide practical recommendations in order to improve Ukraine's international broadcasting system. The author also outlines the directions of its reformation. The expansion of international broadcasting is defined as a priority vector of the international media communications of our country.

Key words: foreign broadcasting, media communications, international broadcasting, international information policy, state information sovereignty.

\section{ІНОМОВЛЕННЯ ЯК ФОРМА ЗОВНШШНЬОПОЛТТИЧНИХ МЕДІА-КОМУНІКАЦІЙ СУЧАСНИХ ДЕРЖАВ: ДОСВІД ДЛЯ УКРАЇНИ}

\author{
Уляна Ільницька \\ Національний університет “Львівська політехніка” \\ uv11@i.ua \\ ORCID: 0000-0002-9103-3144
}

\begin{abstract}
Комплексно досліджено проблему ефективності іномовлення у системі зовнішньополітичних медіакомунікацій сучасних держав 3 метою запровадження та використання позитивного зарубіжного досвіду для України. Проаналізовано значення іномовлення у реалізації зовнішньополітичних стратегій сучасних держав та обгрунтовано його визначальну роль у позиціонуванні та популяризації держав на міжнародній арені, створенні позитивного іміджу країни. Доведено, що ефективно організована система іномовлення - результативна форма комунікації країни зі світовою громадськістю, важливий напрям зовнішньої політики, ефективний інструмент у захисті національних інтересів.
\end{abstract}




\begin{abstract}
Охарактеризовано основні етапи становлення іномовлення як складової медіа-комунікацій сучасних держав; проаналізовано організаційні та політико-правові засади й принципи функціонування системи іномовлення провідних зарубіжних країн у глобальному інформаційному просторі.

На основі аналізу зарубіжного досвіду функціонування іномовних інститутів надано практичні рекомендації щодо удосконалення системи іномовлення України та окреслено напрями їі реформування.

Ключові слова: іномовлення, медіа-комунікаиії, міжнародне мовлення, міжнародна інформаційна політика, інформачійний суверенітет держави.
\end{abstract}

Information globalization processes in the modern world determine the foreign-policy communications vectors of the modern states. The 21 st century is characterized by the widespread usage of infocommunication media technologies and the creation of an effective system of informing the world community about current events and processes of domestic and foreign policy by each state. A virtuous mechanism for the implementation of the foreign-policy infocommunication strategy of the modern states is the broadcasting (foreign broadcasting, international broadcasting) - the form of activity, based on mediainforming the world community, representing objective, relevant information about the country, its values, principles, priorities and core vectors of domestic and foreign policy through the international mass media. Broadcasting is an important media tool for forming the world public opinion, creating and maintaining a positive political image of a certain state, a mechanism for protecting its national interests and counteracting negative information impacts.

The experience of the lead countries in creating a foreign broadcasting system and successful implementation of the information policy give rise to the use of foreign experience in the formation of effective Ukraine's international broadcasting system with a view to objectively media-informing the global public. After all, today there is no qualitative or objective national information product in Ukraine that would effectively distribute complete and truthful data about the contemporary state and actual events in our country. The world community receives limited, distorted, and sometimes false information from foreign media resources about Ukraine. Russian military aggression has also led to the revitalization of a powerful media resource, based on disinformation, manipulation, propaganda and distortion of reality. In global space the perception of Ukraine is often superficial, fragmentary and distorted, which is the result of not only the negatively targeted info-psychological policy or hostile activity of the entities in international relations concerning our country, but also the lack of attention of the Ukrainian authorities to the implementation of an active foreign-policy information policy and the formation of the international broadcasting system. Within the international communication system, there is no single purposeful state policy aimed at promoting Ukrainian interests in the world information space.
Therefore, the priority task of Ukraine's international information policy is the creation of an effective international broadcasting mechanism that will facilitate the dissemination of objective information about Ukraine, the creation of a positive public perception, the implementation of the European integration vector of foreign policy, as well as an expansion of opportunities and prospects for the development of our state.

Relevance of the topic caused a considerable interest of scientists in this dimension. The phenomenon of foreign broadcasting is the subject of research by many scholars and theorists in the field of international relations. Foreign broadcasting as a constituent of foreign-policy media communications was studied by Zernetska, Kudriavtseva, Makarenko, Tykhomyrova and Yurychko. The study by domestic scientists and journalist practitioners is devoted to the research of the functioning of Ukraine's foreign broadcasting. In this context we should mention Bezzub, Dzholos, Konakh, Lyzanchuk, Mashchenko, Skofenko and others. However, in the explanatory works of the abovementioned scholars, there was no integrated or thorough analysis of the role of international broadcasting in promoting the national interests, preserving information sovereignty or counteracting misinformation and propaganda. The foreign experience of organizing the international broadcasting and the creation of practical recommendations for the formation of an effective Ukraine's foreign broadcasting system require further indepth consideration.

The urgency of the research topic and the lack of scientific development of this issue defined the objective of the article - to study the issue of the effectiveness of international broadcasting in the system of foreign-policy media communications of the modern states integrally and thoroughly with a view to introducing and using positive foreign experience for Ukraine. According to the research goal, we set the following tasks: to define the essence of the notion of "international broadcasting" and its role in positioning different states in the international arena, protecting their information sovereignty, popularizing and creating the image of a certain country; to analyze the history and the main formative stages of international broadcasting as a constituent of modern media communications; to investigate the organizational and politico-legal principles of functioning the international broadcasting system of foreign countries in global information space and to identify their common 
features at the present stage; to consider the foreign experience of the functioning of Ukraine's international broadcasting institutes and structures, to systematize the principles of their functioning; to characterize the main stages of the formation and transformation of Ukraine's international broadcasting system; to consider the regulatory framework and principles of the functioning of Ukraine's foreign broadcasting system; to provide practical recommendations for the creation of an effective system of Ukraine's international broadcasting system and to outline the directions of its reforming on the basis of the analysis of the foreign experience of the functioning of the foreign broadcasting institutes.

Broadcasting (foreign broadcasting, international broadcasting), organized and implemented by a certain state in the global information space, is one of the most important mechanisms of communication between the country and the international community and an effective instrument of state foreign policy, since it implies massive influence on public opinion. Broadcasting as a specific form of activity remains an important tool for the majority of countries in the world to promote and protect national interests abroad, to preserve the state information sovereignty, to form and maintain a positive foreign-policy image of the country in the world. The priority task of international broadcasting campaigns is to inform foreign audiences about a certain country's sociopolitical, economic, and cultural life and to explain the position of a particular state on important and topical issues of domestic and foreign policy. Expansion of international broadcasting is a matter of international prestige of a define state in the world, a matter of strategic importance.

From the time of its appearance, broadcasting has evolved significantly from small-scale radio services to powerful multimedia corporations, which widely apply radio, television and the Internet in their activities. Through audiovisual media, Internet technology and online platform information is dynamically distributed to the whole international community.

Foreign broadcasting is a specific form of media activity of a particular state aimed at citizens of other countries in order to make a certain info-psychological impact on them. This activity presupposes the preparation and transmission of information messages, news, analytical programs [Конах, 2014: 12]. A powerful system of international broadcasting should provide a complete, objective and structured information picture of events in the state, the main vectors of its foreign and domestic policies. Foreign broadcasting must function as a source of objective, relevant, impartial and reliable information. The ultimate information product of the international broadcasting system is the official position of the state. The orientation of international broadcasting is not the internal public of the state, but the international community, foreign political, governmental, business, expert, media, cultural, scientific circles, as well as diaspora.

The entities of the international broadcasting system are obliged to adhere to the following principles in their activities: transparency and openness of functioning; non-interference in the internal policy of the states where the international broadcasting is spread; respect for the moral, religious, ideological and philosophical beliefs of any foreign audience; prevention of discrimination on any grounds; objectivity, accuracy, impartiality and reliability of information, strict separation of facts from comments and evaluations; adherence to the highest professional standards of journalism; free expression of views, thoughts and beliefs; freedom of speech.

Given the sociopolitical significance, funding for the international broadcasting system is mostly carried out from the state budget. The system of broadcasting should be created by a define state and function not only as a content delivery channel, but also as a producer that will supply content to major world news agencies and other media. At the present stage, the international broadcasting system operates as multimedia campaigns, which use multimedia platform for the influence on international audience - a combination of various platforms: long-, medium-, and shortwave radio, television, satellite broadcasting, the Internet.

In the modern system of foreign-policy media communications, the purpose of the international broadcasting is to protect the national interests and state information sovereignty in the system of international relations; to ensure integration into the global world information space and to form a positive image of the country.

The stated goals involve solving the tasks of the international broadcasting as a form of foreign-policy media communications using by the modern states: prompt, objective, complete, timely, unbiased, comprehensive and balanced informing of the foreign audience about socially important events in the state, its internal and external policies, activity of the government and local self-government authorities, as well as the country's position on international issues; 2) dissemination of ideological, cultural and other values of the broadcaster in the world and popularization of the country; 3) raising the general awareness of the international community about the country and its individual regions; 4) providing the foreign audience with the required information products; 5) providing a platform for worldwide debate on the official position of public authorities on important topics, in particular in the fields of politics, culture and economics, in order to promote mutual understanding and exchange of ideas between different cultures and nations of the world; 
6) intensification of international dialogue and cultural exchange [Розкладай 2015]; 7) counteraction to negative information attacks and minimization of propaganda impacts; 8) promoting the strengthening of the international credibility of the country; 9) maintaining links with compatriots abroad.

In the history of the formation and functioning of the international broadcasting, it is possible to distinguish three stages. The first stage -20 s of the twentieth century - the emergence of radio and namely radio broadcast, used by the leadership of many states as a powerful means of shaping world public opinion, influence on the consciousness of the international community, as well as a mechanism for representing the positions of its own state. The broadcast begins with the first foreign broadcasting services: in the USSR in 1923 - "Moscow Radio", in Germany in 1926 - "Nauen and Zeesen", in Italy in early 1932 - "Vatican Radio", in the UK - "BBC World Service" (1932). In 1942, the first foreign broadcasting service "Voice of America" began transmissions in the United States, as a counterbalance to the German propaganda of Goebbels [Беззуб 2015].

The second stage of the development of international broadcasting is associated with the period of the Cold War under the bipolar system. International foreign broadcasting was widely applied by communist and anti-communist blocs to propagate and affect population of both sides. The most influential institutions of that time were American "Voice of America", "Radio Free Europe/Radio Liberty", British "BBC World Service", German - "Deutsche Welle" (since 1953) [Еволюція іномовлення... 2014]. At that time, other countries of Europe, as well as the countries of the Middle East and Africa began to develop international broadcasting actively.

The third stage is the 90s of the twentieth century - the end of the Cold War and the collapse of totalitarian regimes in the countries of the socialist camp. Meanwhile, it is also monitored the transformation of foreign states' international broadcasting from the "alternative" to the "integrated" broadcasting of young democracies in the countries of Central and Southeast Europe [Еволюція іномовлення ... 2014]. The decisive feature of this stage is the legalization of the Western countries' foreign broadcasting of the former Soviet republics. Digital audio broadcasting and satellite television appear during this period.

At the present-day stage, the development of the international broadcasting is dynamic due to the Internet, which is used by foreign radio and television companies as a platform for hosting their content. "Hybrid broadcasting" is widely used when text, audio and video information is hosted on the Internet sites. Nowadays, the leaders in the global foreign broadcasting space are Arabic "Al Jazeera", Chinese "CCTV", Russian "Russia
Today", British "BBC World News", American "CNN International", and French "France24" [Еволюція іномовлення... 2014].

There are a lot of common features in the functioning of modern-day international broadcasting, organized by foreign states. Scientist Konah distinguishes such features:

1. International language services remain an important tool for the dissemination of ideological, cultural and other values of the broadcasters in the world, a mechanism for protecting the national interests of any state abroad.

2. International broadcasting $\mathrm{TV}$ and radio structures operate under the auspice of the state. So, in the US, "Voice of America", "Radio Marti" and "TV Marti" have the status of federal programs. In the UK, "BBC World Service" is subordinated to the UK Foreign Office. In France, all international broadcasting TV and radio channels are merged into the state holding AEF Médias Monde.

3. The broadcasting is carried out at the expense of funds allocated from the state budget. State funding is provided to the "BBC World Service Radio" (UK), "Deutsche Welle" (Germany), "TV5 MONDE" and "France 24" (France). In the United States, financing of all foreign broadcasting services that are part of the International Broadcasting Bureau is carried out from the federal budget. In Japan, international broadcasting TV and radio channels receive significant financial support from the government.

4. In order to influence the target groups of the world community, broadcasters use a combination of different platforms: long-, medium- and shortwave radio, satellite broadcasting, as well as the Internet.

5. Leading international broadcasting services have a significant number of language editors. In particular, the staff of the US foreign broadcasting services prepares and releases programs in English and another 60 foreign languages [U.S. Agency for Global Media 2019]. "BBC World Service Radio" has been broadcasting in 44 languages for a long time, and only for the last decade it has reduced the number of languages to 32. "The German Wave" is broadcast in more than 30 languages.

6. In some countries (the USA and Germany), it is legally prohibited to engage international broadcasting directly to the audience of their own country.

7. The current trend in the functioning of the international broadcasting system is the association of foreign broadcasting services in media holdings [Конах 2014: 15-16].

The emergence of Ukraine as an active entity of international relations and the implementation of its Eurointegration aspirations require the active introducing of foreign-policy media communications, popularizing 
the state in the world, promoting the national interests in the world information space. A priority task in the process of integrating Ukraine's national information infrastructure into European and global information infrastructures is the formation of an effective system of informing and providing information support to the state policy of Ukraine beyond its borders.

The implementation of foreign-policy media communications by Ukraine through the creation of a system of international broadcasting has intensified only in the twenty-first century. But, the basis for the implementation of international information policy was formed in Ukraine during the Soviet period of history. The functioning of the domestic international broadcasting originates from 1950, when the first foreign broadcasting editorial office "Radio Kyiv" was created in order to promote the Soviet way of life, popularize of Ukrainian culture, language and everyday life. In 1991, after the collapse of the USSR, "Radio Kyiv" was renamed to the Worldwide Radio Broadcasting Service of Ukraine (WRBSU) with the broadcasting title "Radio Ukraine International". The content of the broadcasting was reoriented to the new tasks faced by independent Ukraine. Since the 2000s, the WRBSU broadcasting occurs on the Internet and via satellites. Since 2003, Ukraine's foreign broadcasting is conducted through the Ukrainian Television and Radio "International Service "Ukrainian Television and Radio Broadcasting" on the satellite channel "Express". The volume of Ukrainian international broadcasting consists 72 hours per day: 24 hours to Eurasia and North America on satellite channels, as well as 24 hours Internet Broadcasting [Конах 2014: 16-19]. Starting from September 1, 2012, the satellite channel of National Television Company of Ukraine (NTU) - "Pershyi Ukraine" has started broadcasting.

Another national information resource to distribute information about our state abroad is the Ukrainian National News Agency "Ukrinform", which was formed in November 1996. "Ukrinform" is subordinated to the Cabinet of Ministers of Ukraine. News of the agency is published in Ukrainian, Russian, English, German and Spanish. The correspondents of the agency operate in each region of Ukraine and 11 countries of the world [Еволюція іномовлення... 2014]. On August 24, 2014, the Internet portal Ukraine Today was created in Ukrainian and English versions in order to confront any negative info-psychological impacts and promote Ukrainians values to international community.

In addition to the state, civil society also take initiatives in the framework of the implementation of international information policy. With the initiative of the public, a number of centers have been set up to disseminate information on events in Ukraine. In particular, we should mention: Ukraine Crisis Media
Center (March 2014), "StopFake” (March 2014), Free Voice Information Analysis Center (October 2014), Analytical Center "Borysfen Inte” (December 2012), I Promote Ukraine (October 2014) etc [Беззуб 2015].

In July 2015, the Cabinet of Ministers registered the draft law No. 2334a "On International Broadcasting System of Ukraine" in order to clearly define the legal and regulatory framework for the functioning of foreign broadcasting beyond Ukraine borders. On December 8, 2015, the Verkhovna Rada of Ukraine adopted the Law "On International Broadcasting System of Ukraine" which was signed by the President and came into force on January 16, 2016. According to the Law, the system of state international broadcasting involve the state-run enterprise "The International Broadcasting Multimedia Platform of Ukraine" (UA|TV) and the Ukrainian National News Agency "Ukrinform" [Про систему іномовлення: Закон України 2015]. An information product is broadcast to the world community in English (at least $50 \%$ of the content) and in other languages.

In spite of the intensification of the state policy of Ukraine's foreign broadcasting in the global information space, it should be noted that Ukrainian information product and the whole system of broadcasting are not competitive in the global information market. Ukraine's foreign broadcasting to foreign audience is characterized by insufficient presence in the wave range, a small number of foreign broadcasting editorial offices, and limited total volume of broadcasting in foreign languages and differs from world analogues with low level of financial support. As a result we face such problems as the vulnerability of Ukraine information sovereignty, low awareness of the world community about the state; distorted, fragmentary and biased view of Ukrainian domestic and foreign policy.

In order to improve the system of Ukraine's foreign broadcasting and to ensure the effective implementation of international strategic information communications aimed at raising the level of awareness of the world community about Ukraine, it is necessary to productively apply the foreign experience of the organization of the international broadcasting. Given the overseas foreign broadcasting experience, it is expedient to implement the international information policy of Ukraine on the formation of an effective system of foreign broadcasting in the following areas: preservation of the subordination of foreign-broadcasting services, structures and mass media to the Ukrainian state, and ensuring strong state financial, regulatory and organizational support in the field of broadcasting; association of state foreign broadcasting services in media holdings, which will include television, radio and internet broadcasting [Конах 2014: 20]; improvement of funding for Ukraine's international broadcasting system, ensuring its transparency; improvement of the legislative 
framework for the functioning of Ukraine's international broadcasting system and its adaptation to international standards; improvement of the qualitative content of Ukraine's foreign broadcasting and creation of competitive information and analytical programmes; increasing the number of language editors and expanding the range of languages; increasing the time of Ukraine's international broadcasting programs in the world of information space; intensification of Ukraine's cooperation with world media structures and representatives of international media covering Ukrainian issues; the involvement of nongovernmental organizations and associations for the implementation of Ukraine's international broadcasting projects in the world's information space; effective usage of opportunities of Ukrainian cultural information centers abroad to create and disseminate information and image materials about Ukraine; providing cooperation with the Ukrainian diaspora for the dissemination of products of national broadcasting in the world of information space. Thus, the application of foreign experience of the leading countries will create an effective and productive Ukraine's international broadcasting system.

Expansion of international broadcasting of Ukraine is a priority vector of international media communications of our state. After all, effective information support of Ukraine's foreign and domestic policy and development of the functional mechanism of international broadcasting will promote consolidation of Ukrainian and foreign societies, popularization of Ukrainian culture; ensure the integration of Ukraine into the European and global information spaces, contribute to strengthening the international credibility of the Ukrainian state and forming of a positive public perception. Objective positioning of Ukraine in international information flows, effective communication with the international community and cooperation with world media structures are an important prerequisite for ensuring both national interests and Ukraine information sovereignty and security. The transformation of an existing state's international broadcasting resource into an effective instrument of international information policy of Ukraine abroad is possible with the usage of foreign experience of the leading countries regarding the formation of an effective international broadcasting system.

Prospects for further research are the problems of the formation of an effective international broadcasting system within the European information space and the development of effective means and mechanisms for combating information propaganda, disinformation and cybercrime. In addition, a comprehensive study needs an issue of Ukraine's international broadcasting modification and its transformation into an effective tool for the promoting Ukraine information sovereignty; development of effective institutional and political-legal mechanisms for implementation of the international broadcasting system in the international foreign-policy media communication of Ukraine.

\section{ЛІТЕРАТУРА}

Беззуб, І. (2015). Іномовлення України: сучасний стан та перспективи розвитку. Отримано $3 \mathrm{http} / / /$ nbuviap. gov.ua/index.php?option=com_content $\&$ view=article\&id=1992: inomovlennya-suchasnij-stan-ta-perspektivi\&catid $=8 \&$ Itemid $=350$

Еволюція іномовлення в іноземних державах: досвід для України: Аналітична записка Національного інституту стратегічних досліджень України (2014). Отримано 3 http://www.niss.gov.ua/articles/1493/

Конах, В. (2014). Еволюція іномовлення в іноземних державах: досвід для України. Актуальні проблеми міжнародних відносин, Випуск 118 (Частина 1), 12-24.

Розкладай, І. (2015). Цей невідомий звір іномовлення. Отримано $3 \mathrm{http} / / \mathrm{ms}$.detector.media/trends/ 1411978127/tsey_nevidomiy_zvir_inomovlennya/

“Про систему іномовлення в Україні" (2015): Закон України № 856-VIII від 8 грудня 2015 року. Отримано 3 https://zakon.rada.gov.ua/laws/show/856-19

U.S. Agency for Global Media. (2019). Отримано 3: https://en.wikipedia.org/wiki/U.S._Agency_for_Global_Media

\section{REFERENCES}

Bezzub, I. (2015). Ukraine's International Broadcasting: the Current State and Prospects of Development. [In Ukrainian]. Retrieved from http://nbuviap.gov.ua/index.php?option= com_content\&view=article\&id=1992:inomovlennyasuchasnij-stan-ta-perspektivi\&catid $=8 \&$ Itemid $=350$

International Broadcasting Evolution in Foreign States: Experience for Ukraine: Analytical Note of the National Institute for Strategic Studies of Ukraine (2014). [In Ukrainian]. Retrieved from http://www.niss.gov.ua/articles/1493/

Konah, V. (2014). International Broadcasting Evolution in Foreign States: Experience for Ukraine. [In Ukrainian]. Actual Problems of International Relations, Issue 118 (Part 1), 12-24.

Rozkladai, I. (2015). This Unknown Creature of International Broadcasting. Retrieved from http://ms.detector. media/trends/1411978127/tsey_nevidomiy_

zvir_inomovlennya/

"On international broadcasting system of Ukraine" (2015): Law of Ukraine No. 856-VIII of December 8. Retrieved from https://zakon.rada.gov.ua/laws/show/856-19

U.S.Agency for Global Media. (2019). Retrieved from: https://en.wikipedia.org/wiki/U.S._Agency_for_Global_Media 